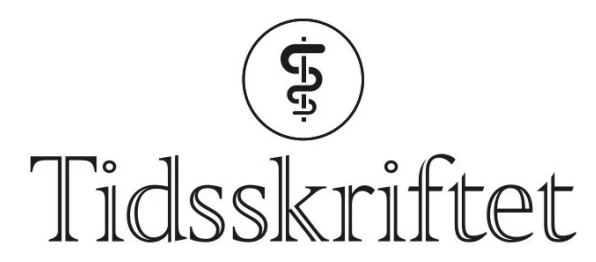

DEN NORSKE LEGEFORENING

\title{
Førstegangspsykose behandlet uten nevroleptika
}

KORT KASUISTIKK

TARAN BURAN NAERDAL

taranburan@gmail.com

Intensivt ungdomsteam

BUPA døgn ungdom

Sykehuset i Vestfold

Taran Buran Nærdal er overlege.

Forfatteren har fylt ut ICMJE-skjemaet og oppgir ingen interessekonflikter.

\section{I den følgende pasienthistorien beskrives en vellykket behandling av en ung pasient med førstegangspsykose, der helhetlig forståelse, tålmodighet samt systemisk arbeid uten bruk av medikamenter førte til tilfriskning.}

Pasienten hadde gjennom hele oppveksten hatt utfordringer knyttet til overganger. Hun hadde alltid hatt sterk vilje, lav frustrasjonstoleranse og manglende følelsesspråk. I barnealder ble hun henvist til den lokale barne- og ungdomspsykiatriske poliklinikken (BUP), som konkluderte med diagnosen Aspergers syndrom. De kommende skoleårene hadde hun behov for en svært tilrettelagt skolehverdag med korte dager og én-til-énundervisning. Overgangen til ungdomsskole ble vanskelig, og hun sluttet etter hvert helt å møte på skolen. Ett år senere ble hun innlagt ved den lokale BUP-avdelingen med en psykotisk tilstand og høy suicidalfare etter inntak av etsende væske.

Ved innleggelsen var hun i kontinuerlig beredskap og framsto som klart psykotisk, med auditive, visuelle og taktile hallusinasjoner. Somatisk og nevrologisk status var normal, og det var ikke mistanke om ruspåvirkning. MR caput og EEG, som ble gjennomført som ledd i psykoseutredningen, viste normale funn. Med tanke på alvorlighetsgrad og symptomutvikling over flere år anså man en lengre innleggelse som nødvendig.

Pasienten beskrev stemmehøring fra 9-10-årsalderen, med økt grad av imperative stemmer det siste året. De siste seks månedene hadde hun begynt å se diffuse, skremmende skygger, og den siste måneden fire tydelige menneskeskikkelser, som hun beskrev i detalj. Hun hadde store vansker med å skille mellom seg selv og stemmene og greide ikke å uttrykke egne behov eller gi selvstendige svar. Hun husket dårlig forhold som ikke handlet om psykotiske opplevelser, hadde ingen minner fra oppvekst/barndom og framsto som desorientert for dato/årstid. Hun beskrev stor grad av selvforstyrrelsessymptomer, særlig usikkerhet knyttet til hva som var virkelig og ikke. Stemmene fortalte henne at hun måtte 
$\mathrm{d} \emptyset$ for å komme til deres verden, og under innleggelsen hadde hun flere suicidalfors $\emptyset \mathrm{k}$, der alle virket psykotisk motivert. Stemmene forbød henne også i stor grad å spise og nektet henne å ta imot medisiner. Pasientens pårørende gjorde en stor innsats for å få i henne tilstrekkelig næring, og det ble aldri alvorlig bekymring for underernæring.

Pasienten ble under innleggelsen tilbudt medikamentell behandling i form av nevroleptika, og det ble gjort mange forsøk på å forberede og motivere henne til å ta imot dette. Hun greide ved to enkeltanledninger å ta imot o, $5 \mathrm{mg}$ risperidon, uten klar effekt eller bivirkninger, men slik at vi visste at hun tålte medikamentet. På grunn av svært høyt symptomtrykk ble bruk av depotinjeksjoner drøftet, både med pårørende, innad i kollegiet og med eksterne kolleger. I samråd med pårørende ble det besluttet å tilby medisiner med jevne mellomrom, men ikke i form av tvungen injeksjon.

En stabil behandlerrelasjon ble etablert og inkluderte gjennom behandlingsløpet en variasjon av intervensjoner i ulike faser, deriblant psykoedukasjon, kognitiv terapi ved psykose, tegning av livshistorie/narrativ og affektbevissthetstrening. Tidligere journal ble gjennomgått, og sammen med jenta og de pårørende ble det jobbet for å få en forståelse av hennes sårbarheter og stressbelastninger gjennom livet. Psykoedukativt familiesamarbeid ved psykose, som er anbefalt behandling i nasjonale faglige retningslinjer for psykoselidelser, ble startet opp under innleggelsen.

Hun ble skrevet ut til en kommunal omsorgsbolig etter seks måneder. Det indre symptomtrykket var relativt uendret. Imidlertid deltok pasienten noe mer i aktiviteter, hadde $ø$ kt ansiktsmimikk og verbal deltakelse. Det ble i kommunal bolig etablert et eget skoletilbud. Individualsamtaler to ganger per uke ble opprettholdt med samme behandler. Fem måneder etter utskrivning fra døgnpost beskrev hun for første gang reduksjon $\mathrm{i}$ hallusinatoriske opplevelser, først i form av fravær av taktile hallusinasjoner.

Etter en stemmestyrt tablettoverdose tilkom en kortvarig forverring i symptomtrykk, fulgt av reduksjon i symptomer. Ti måneder etter utskrivning fra døgnpost beskrev hun for første gang at hun ikke opplevde seg styrt av stemmene og at hallusinasjonene ikke lenger skremte henne. Hukommelsen for både nyere og eldre hendelser kom gradvis tilbake, og hun tilbrakte stadig mer tid hjemme.

Ett år etter utskrivning er stemmehøring og vrangforestillinger helt fraværende. Hun reflekterer godt rundt egen sykdomsprosess og deltar aktivt i egen behandling. Hun bor i hovedsak hjemme, men bruker fortsatt boligen som avlastning. Hun har gjennomført alle skoletentamener og har et rikt sosialt nettverk.

\section{Diskusjon}

I en rekke studier sammenlignes psykosebehandling med og uten legemidler. Få studier omhandler pasienter med førstegangspsykose, men det er likevel ofte antatt at disse pasientene har bedre effekt av medikamenter enn pasienter med et mer kronisk sykdomsforløp (1). En nyere studie viser at pasienter med førstegangspsykose klarte seg like godt med som uten antipsykotisk legemiddelbehandling (므). Inklusjonskriteriene var strenge for å ivareta pasientsikkerheten, og de dårligste pasientene ble derfor ikke inkludert. Studiene gir derfor ikke svar på om medikamentfri behandling også kan være gunstig for disse pasientene. Vi trenger derfor å dele pasienthistorier der behandling uten bruk av medikamenter har vært vellykket og ført til tilfriskning, også for de sykeste pasientene.

Denne pasienten hadde et dårlig prognostisk utgangspunkt, med stor grad av sårbarhet i forkant av psykosesymptomene. Symptomtrykk og sykehistorie under innleggelsen tilfredsstilte kriterier for en tidlig debuterende schizofreni. Pasienten er i ettertid tydelig på at det hadde vært feil å sette injeksjon mot hennes vilje da hun var på det sykeste. Dette ville gjort det enda vanskeligere å stole på oss, i en situasjon der verden for henne var grunnleggende utrygg. Vi var mange ganger i tvil om dette valget, og i dag kan vi ikke vite 
om hennes sykdomsforløp kunne vært forkortet ytterligere ved tvungen medikamentell behandling. Tatt i betraktning mange års sårbarhet og stort behov for tilrettelegging og oppfølging fra både spesialisthelsetjeneste, kommunehelsetjeneste og skole forut for psykosedebut vurderes imidlertid bedringen å ha tilkommet relativt raskt, stabilt og på mange livsområder uten bruk av medikamenter. Hun er selv klar over sin sårbarhet og vet at hun har en risiko for å utvikle nye psykotiske episoder dersom hennes individuelle stressbelastning blir for stor.

Som en del av kunnskapsgrunnlaget rundt medikamentell psykosebehandling, og før forskningen gir oss bedre svar, trenger vi å dele slike erfaringer. Også for de sykeste pasientene kan det i noen tilfeller være forsvarlig å avvente medikamentell behandling.

Pasienten og begge foresatte har gitt samtykke til at artikkelen blir publisert. Artikkelen er fagfellevurdert.

\section{LITTERATUR}

1. Leucht S, Leucht C, Huhn M et al. Sixty years of placebo-controlled antipsychotic drug trials in acute schizophrenia: Systematic review, bayesian meta-analysis, and meta-regression of efficacy predictors. Am J Psychiatry 2017; 174: 927-42. [PubMed][CrossRef]

2. Francey SM, O'Donoghue B, Nelson B et al. Psychosocial intervention with or without antipsychotic medication for first-episode psychosis: A randomized noninferiority clinical trial. Schizophrenia Bulletin Open 2020; 1: sgaao15. [CrossRef]

Publisert: 22. november 2021. Tidsskr Nor Legeforen. DOI: 10.4045/tidsskr.21.0317

Mottatt 14.4.2021, første revisjon innsendt 27.5.2021, godkjent 22.6.2021.

Publisert under åpen tilgang CC BY-ND. Lastet ned fra tidsskriftet.no 26. april 2023. 